\title{
THE INFLUENCE OF FATTY ACID COMPOSITION ON THE KINETICS OF THE VEGETABLE OIL METHANOLYSIS REACTION
}

Milan D. Kostić ${ }^{1, *}$, Olivera S. Stamenković ${ }^{1}$, Vlada B. Veljković ${ }^{1,2}$

${ }^{1}$ Faculty of Technology, University of Niš, Leskovac, Serbia

2 The Serbian Academy of Sciences and Arts, Belgrade, Serbia

The base-catalyzed methanolysis of roadside pennycress, olive, melon, grapeseed, hempseed, sunflower, and plum kernel oils was performed in the presence of $\mathrm{KOH}\left(1 \%\right.$ to the oil weight) at the temperature of $60^{\circ} \mathrm{C}$ and the methanol/oil molar ratio of $6: 1$. The aim of this work was to reveal the influence of the fatty acid composition of the oils on the kinetics of these methanolysis reactions. The irreversible pseudo-first-order reaction was used for modeling the kinetics of the methanolysis reactions, and the reaction rate constant was correlated with the content of unsaturated fatty acids in the oil. The value of the reaction rate constant increases linearly with increasing the unsaturated fatty acids content in the oil. The applicability and reliability of the model were confirmed by high values of the coefficient of determination and low values of the mean relative percentage deviation between the calculated and experimental triacylglycerols conversion degree.
(ORIGINAL SCIENTIFIC PAPER)

UDC 662.756.3:66.09

DOI 10.5937/savteh2102024K
Keywords: biodiesel; kinetics; methanolysis; oil; unsaturated fatty acids

\section{Introduction}

The global warming problems and the growing demand for fuel are leading the scientific community to search for new fuel types. Special attention has been paid to biodiesel, bioethanol, and biogas. Biodiesel is one of the promising fuels that consisting of a mixture of fatty acids alkyl esters. It is most often obtained by transesterification of triacylglycerols (TAG) with low aliphatic alcohols in the presence of a catalyst. Methanol is the most frequently used alcohol, due to its higher reactivity, lower price, and easy availability compared to ethanol.

The use of biodiesel as a widespread fuel is still limited by its price, which is mostly influenced by the TAG source, as much as $75 \%$ of the total biodiesel price [1]. Currently, edible vegetable oils, such as rapeseed, palm, soybean, and sunflower oil, are the most used feedstocks for biodiesel production, but they are primarily used in human nutrition. Therefore, many researchers are directed towards the utilization of non-edible and waste oily feedstocks as TAG sources. So far, many inedible oils [2-6], waste oils from food preparation [710], as well as animal fats [11-15], have been used successfully in the fatty acids alkyl esters synthesis. Also, the sources of TAG, having different fatty acid compositions, greatly affect the biodiesel properties. From the biodiesel quality point of view, oily feedstocks for biodiesel production should contain as small as possible a content of polyunsaturated fatty acids because the oils rich in polyunsaturated fatty acids have low oxidative stability and a high iodine value.

The widely used catalysts for biodiesel production are homogeneous base catalysts due to their high catalytic activity and low price. The main drawbacks of these catalysts are the impossibility to catalyze the alcoholysis of low-quality oily feedstocks containing high free fatty acids (FFA) amounts and the fact that they cannot be reused, as well as the need for biodiesel purification that generates huge wastewater. Some disadvantages of homogeneous catalysts could be overcome by using heterogeneous and enzyme catalysts that have been intensively investigated recently. So far, calcium oxide has been widely used in heterogeneously catalyzed alcoholysis due to its availability, low price, and simple handling. The various waste materials have been used as calcium oxide sources, such as eggshells of different poultry species $[16,17]$, mollusk shells $[18,19]$, and agricultural biomass [20-23]. Some researchers have also dealt with increasing the activity of calcium oxide in the production of biodiesel, by adding organic [24] and eutectic solvents [25] as cosolvents.

The kinetic modeling is of crucial importance for the simulation, control, techno-economic analysis, improvement, and development of processes at pilot and industrial scales. Different kinetic models have been used in the previous kinetic studies of the homogeneously catalyzed methanolysis. According to one group of researchers, the kinetics of the overall methanolysis reaction can be described as an irreversible pseudo- 
first-order reaction [26-30]. On the other side, some researchers suggest the irreversible pseudo-secondorder kinetic model $[2,10]$. A more complex reaction mechanism consisting of three consecutive reversible reactions following the second-order reaction kinetics has also been used [31,32].

The present paper deals with the methanolysis of the oils obtained from roadside pennycress, melon, hemp, sunflower, olive, and grape seeds, as well as plum kernels. The major aims are to investigate the influence of oils' fatty acid composition on the reaction rate and to model the kinetics of these methanolysis reactions. The methanolysis reaction kinetics is modeled by the irreversible pseudo-first-order reaction. The obtained reaction rate constants are correlated with the unsaturation degree of the tested oils.

\section{Experimental}

Materials and chemicals

Grapeseed oil (GO), olive oil (OO), and sunflower oil (SO) were purchased in a local supermarket and hempseed was procured at a local market. Roadside pennycress was harvested on the Pasjača Mountain (south of Serbia) while melon seeds and plum kernels were collected from a household (Žitorađa, Serbia). Before use, the seeds and kernels were stored in paper bags in a dark room. Methanol and $n$-hexane (both HPLC grade) were obtained from Promochem LGC (Germany), and 2-propanol, also HPLC grade, from Carlo Erba (Italy). Hydrochloric acid $(36.5 \%)$ and $\mathrm{KOH}(85 \%)$ were purchased from Centrochem (Serbia) and Merck-Alkaloid (FYR of Macedonia), respectively.

Recovery and characterization of the oils

Roadside pennycress oil (RPO), hempseed oil $(\mathrm{HO})$, and plum kernels oil ( $\mathrm{PO})$ were obtained by cold pressing using a hydraulic oil press (Komet, Germany) through $8 \mathrm{~mm}$ nozzles. The obtained oils were filtered under vacuum to remove the residual solids. The extraction of melon seed oil (MO) was carried out in a Soxhlet apparatus using $n$-hexane as a solvent at a solvent-to-seed ratio of 10:1 v:w for $3 \mathrm{~h}$. The obtained liquid extract was evaporated at $50{ }^{\circ} \mathrm{C}$ under vacuum (Hei-VAP, Heidolph, Germany) to constant weight.

Acid and iodine values of the obtained oils were determined by AOCS official methods [33]. The fatty acid composition of the oils was determined by gas chromatography after their methylation as described elsewhere [34].

Equipment, reaction conditions, and experimental procedure of the oil methanolysis

Methanolysis of the tested oils was carried out in a three-neck flask $(250 \mathrm{ml})$ equipped with a reflux condenser and a magnetic stirrer (600 rpm). The flask was set in a thermostated water bath at the desired reaction temperature. The reactions were performed at methanol/oil molar ratio $6: 1$, in the presence of $\mathrm{KOH}$ as a cat- alyst ( $1 \%$ based on the oil weight) at $60{ }^{\circ} \mathrm{C}$ and under atmospheric pressure. Initially, the reactor was charged with the desired amounts of methanol and $\mathrm{KOH}$, and the mixture was thermostated at $60{ }^{\circ} \mathrm{C}$. Afterward, the oil (thermostated separately) was added to the reaction flask and the reaction was timed. The reaction mixture samples $(0.5 \mathrm{ml})$ were taken during the reaction and immediately neutralized by an $\mathrm{HCl}$ solution $(11 \% \mathrm{vol})$ to stop the reaction. The oily-ester layer was separated by centrifugation (Sigma, Germany) at 3,500 rpm and dissolved in 2-propanol: $n$-hexane $(5 / 4 \mathrm{v} / \mathrm{v})$ mixture in the ratio of $1: 200$, filtered through a $0.45 \mu \mathrm{m}$ Millipore filter, and analyzed by the HPLC method [35]. The TAG conversion degree $\left(x_{A}\right)$ was calculated from the TAG content in the reaction mixture at the beginning and any time of the reaction ( $T A G_{0}$ and $T A G$, respectively, in \%) using the Eq. (1):

$$
x_{A}=1-\frac{T A G}{T A G_{0}} \text {. }
$$

Modeling the methanolysis reaction kinetics

The methanolysis reaction consists of three reversible, simultaneous reactions through which TAG is stepwise converted to diacylglycerol, monoacylglycerol, and glycerol. In every reaction step, one mol of methyl ester is obtained. The following overall reaction has mostly been used for the kinetic modeling:

$A+3 B \leftrightarrows 3 R+S$

where $A$ is TAG, $B$ is methanol, $R$ is FAME, and $S$ is glycerol

In modeling the methanolysis reaction, it is assumed that:

a) the reaction mixture is a pseudo-homogeneous system having a uniform composition due to an intensive agitation $(600 \mathrm{rpm})$, so the overall reaction is controlled by chemical reaction and there are no mass transfer limitations,

b) the methanolysis reaction is considered as irreversible pseudo-first-order with respect to TAG because of the methanol excess,

c) the neutralization and saponification reactions can be neglected due to an insignificant FFA content in the oils and a low initial catalyst amount.

Based on the assumptions a) and b), the TAG conversion rate can be expressed by Eq. (3) [10]:

$\left(-r_{A}\right)=-\frac{d c_{A}}{d t}=k_{1} \cdot c_{A}$

where $k_{1}$ is the rate constant of the irreversible pseudo-first-order reaction, $C_{A}$ is the TAG concentration and $t$ is time. If the TAG concentration, $C_{A}$, is expressed via the TAG conversion degree, $x_{A}$, and the initial TAG concentration is $C_{A 0}$, the following equation is obtained: 
$\left(-r_{A}\right)=-\frac{d c_{A}}{d t}=k_{1} \cdot c_{A 0} \cdot\left(1-x_{A}\right)$

and after integration:

$$
-\ln \left(1-x_{A}\right)=k_{1} \cdot t
$$

The rate constant for the irreversible pseudo-first-order reaction can be obtained as the slope of the linear dependence $-\ln \left(1-x_{A}\right)=f(t)$.

\section{Results and discussion}

Fatty acid compositions of the oils

In Table 1, acid and iodine values and fatty acid compositions of the used oils, the oil yield in the case of oils recovered either by cold pressing or solvent extraction of seeds, the total amount of saturated and unsaturated fatty acids, and the average number of carbon atoms in the fatty acid chain (CL) are presented.

Generally, there are differences in the qualitative composition of the used oils. Palmitic and stearic acid are the dominant saturated fatty acids (SFA) while the major unsaturated fatty acids (UFA) are oleic, linoleic, and linolenic acid. The content of behenic acid was significant in RPO and low in $\mathrm{HO}$ while it was not detected in the other oils. Linolenic, arachidic, eicosenoic, and behenic acids were not detected in PO. Palmitic acid is the most abundant SFA except in RPO that is rich in behenic acid. The most present UFA in RPO, OO, and $\mathrm{PO}$ is oleic acid while linoleic acid is the major fatty acid in $\mathrm{MO}, \mathrm{GO}, \mathrm{HO}$, and $\mathrm{SO}$. The quantitative composition of the tested oils varied. However, all oils are rich in UFA with content in the range from 73.42 to $92.61 \%$ while the content of SFA is significantly lower and amounts from $7.31 \%$ to $26.38 \%$. The determined iodine values are in accordance with the fatty acid composition of the oils; $\mathrm{HO}, \mathrm{GO}, \mathrm{SO}$, and $\mathrm{MO}$, which contain predominantly linoleic acid ( $>56 \%$ ) have higher iodine values. Such high iodine values of these oils can limit their use in biodiesel production since the European biodiesel standard EN 14214 restricts iodine value to $120 \mathrm{~g} \mathrm{I}_{2} / 100 \mathrm{~g}$. However, this problem can be solved by using bifunctional catalysts [36] or by adding natural antioxidants [37]. The acid values of the oils are below $2 \mathrm{mg} \mathrm{KOH} / \mathrm{g}$, so the FAME synthesis can be performed by direct base-catalyzed methanolysis.

Table 1. Fatty acid composition of the oils

\begin{tabular}{|c|c|c|c|c|c|c|c|}
\hline Oil & RPO & 00 & $\mathrm{MO}$ & GO & $\mathrm{HO}$ & SO & $\mathrm{PO}$ \\
\hline $\begin{array}{l}\text { Extraction } \\
\text { method }\end{array}$ & Pressing & $\begin{array}{l}\text { Commercial } \\
\text { (pressing) }\end{array}$ & Soxhlet & $\begin{array}{l}\text { Commercial } \\
\text { (pressing) }\end{array}$ & Pressing & $\begin{array}{l}\text { Commercial } \\
\text { (pressing, } \\
\text { solvent } \\
\text { extraction) }\end{array}$ & Pressing \\
\hline $\begin{array}{l}\text { Oil yield, } \\
\text { g/100 g }\end{array}$ & 18.16 & - & 26.05 & - & 26.89 & - & 33.84 \\
\hline $\begin{array}{l}\text { Acid value, } \\
\mathrm{mg} \mathrm{KOH} / \mathrm{g} \text { oil }\end{array}$ & 1.37 & 0.64 & 0.68 & 0.44 & 0.78 & 0.35 & 1.98 \\
\hline $\begin{array}{l}\text { lodine value, } \\
\mathrm{g} \mathrm{I}_{2} / 100 \mathrm{~g}\end{array}$ & 99.3 & 80.0 & 126.2 & 133.9 & 153.2 & 128.9 & 98.6 \\
\hline C16:0, \% & 5.82 & 12.44 & 9.23 & 6.72 & 6.25 & 6.85 & 5.59 \\
\hline C18:0, \% & 1.84 & 2.68 & 5.37 & 3.93 & 2.96 & 3.45 & 1.72 \\
\hline C18:1, \% & 36.05 & 74.77 & 23.70 & 22.82 & 13.99 & 29.31 & 70.85 \\
\hline C18:2, \% & 33.27 & 8.54 & 60.50 & 65.62 & 56.33 & 59.60 & 21.76 \\
\hline C18:3, \% & 4.10 & 0.24 & 0.10 & 0.18 & 15.63 & 0.12 & \\
\hline $\mathrm{C} 20: 0, \%$ & 1.37 & 0.90 & 0.16 & 0.20 & 0.93 & 0.04 & \\
\hline $\mathrm{C} 20: 1, \%$ & & 0.42 & 0.96 & 0.21 & 3.47 & 0.15 & \\
\hline $\mathrm{C} 22: 0, \%$ & 17.35 & & & & 0.47 & & \\
\hline SFA, $\%$ & 26.38 & 16.02 & 14.76 & 10.85 & 10.61 & 10.34 & 7.31 \\
\hline UFA, $\%$ & 73.42 & 83.97 & 85.26 & 88.83 & 89.42 & 89.18 & 92.61 \\
\hline $\mathrm{CL}$ & 18.51 & 17.65 & 17.75 & 17.75 & 17.92 & 17.71 & 17.82 \\
\hline
\end{tabular}

\section{Base-catalyzed methanolysis}

The change of the reaction mixture composition with time in the case of the PO methanolysis is presented in Figure 1. The same dependencies were observed for all used oils. The FAME content increased rapidly at the beginning of the reaction, indicating that the mass transfer did not limit the methanolysis reaction rate. After the period of the fast FAME formation, the reaction rate decreased, and FAME content increased slowly and finally reached equilibrium. The content of TAG decreased during the reaction following the increase of FAME content. The contents of MAG and DAG first increased, reached a maximum, and then decreased and remained almost constant. Generally, the MAG and DAG contents in the reaction mixture were very low due to their fast conversion rate. 


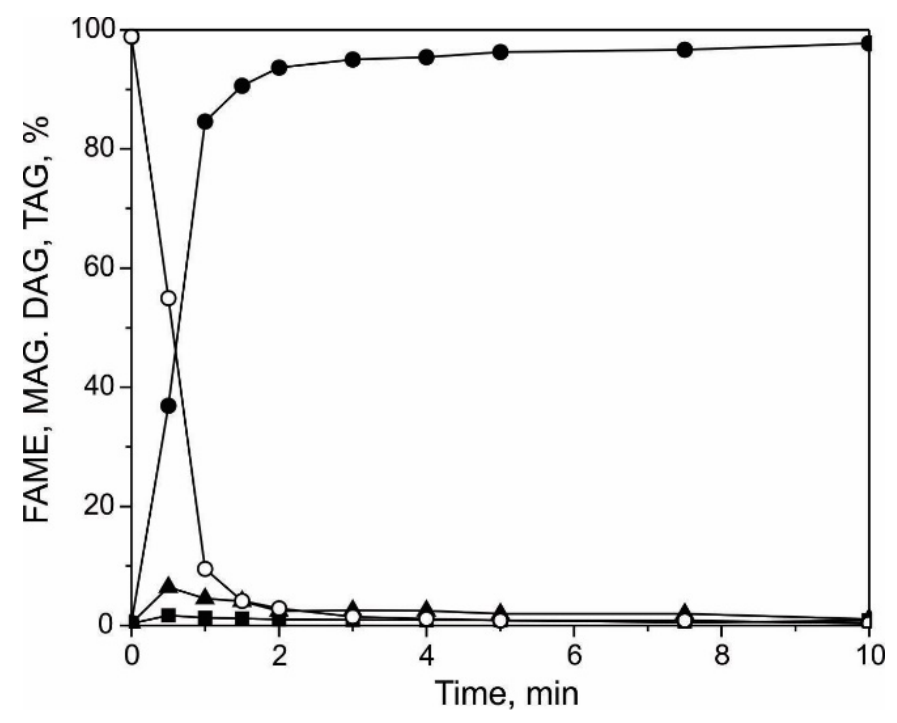

Figure 1 The change of the reaction mixture composition with the progress of the PO methanolysis (• - FAME, $\Delta$ - MAG, - DAG, ० - TAG)

Figure 2 shows the variations of FAME content with time in the methanolysis of RPO, OO, MO, GO, HO, SO, and $\mathrm{PO}$. As can be seen, the FAME synthesis is lowest in the case of the RPO methanolysis and fastest in the PO methanolysis, which can be attributed to the increase of the TAG conversion rate with the increase of the UFA content in the oil. The influence of oil composition on FAME synthesis was observed by other researchers who reported that the methanolysis reaction is faster in the case of oils with a higher unsaturation degree and longer fatty acid hydrocarbon chains $[38-40,15]$.

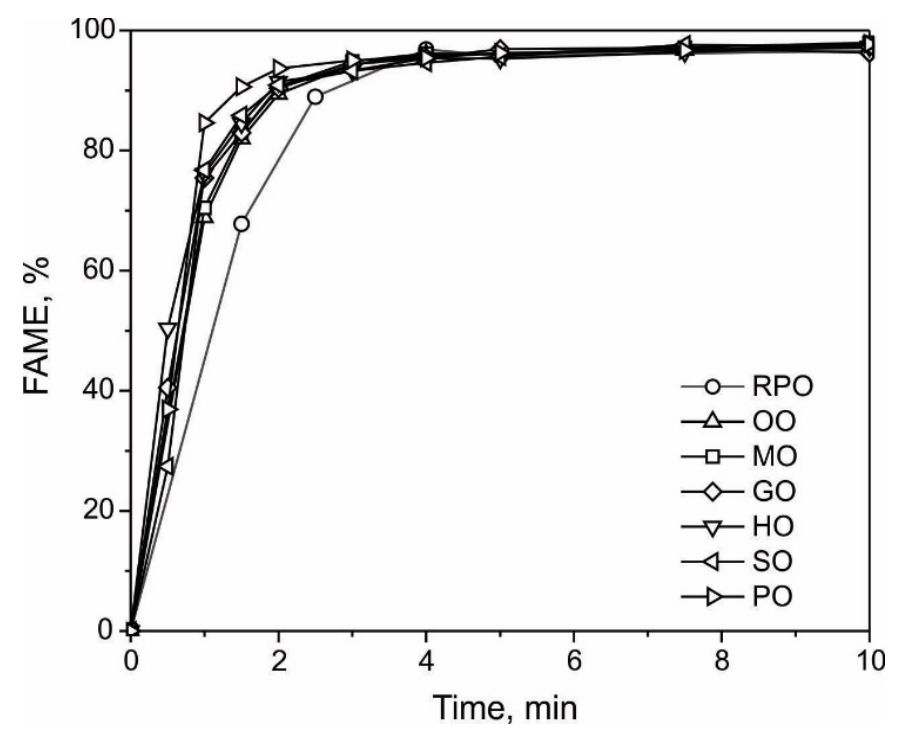

Figure 2 The variation of FAME content during the methanolysis of various oils

Modeling the methanolysis reaction kinetics

To model the kinetics of the overall methanolysis reaction of all used oils, the irreversible pseudo-first-order reaction rate law was accepted. According to Eq. (5),
Figure 3 shows the dependence $-\ln \left(1-x_{A}\right)=f(t)$. The rate constants of the irreversible pseudo-first-order reactions are calculated from the slope of the linear correlation and their values are presented in Table 2 . It can be concluded that the rate constant increases with increasing the UFA content in the oils from RPO to PO. Additionally, Table 2 shows the irreversible pseudo firstorder reaction rate constants for methanolysis reactions of several other oily and fatty feedstocks like heated lard $(\mathrm{HL})$, lard $(\mathrm{L})$, and waste lard (WL) [15], waste cooking oil (WCO) [10], Onopordum acanthium L. seed oil (OAO) [2], and Sinapis alba L. seed oil (SAO) [4] conducted under the same reaction conditions (temperature of 60 ${ }^{\circ} \mathrm{C}$, methanol/oil molar ratio of $6: 1$ and $1 \%$ of $\mathrm{KOH}$ ). The increase of the reaction rate constant with increasing the UFA content in the lard was observed by Stojković et al. [15].

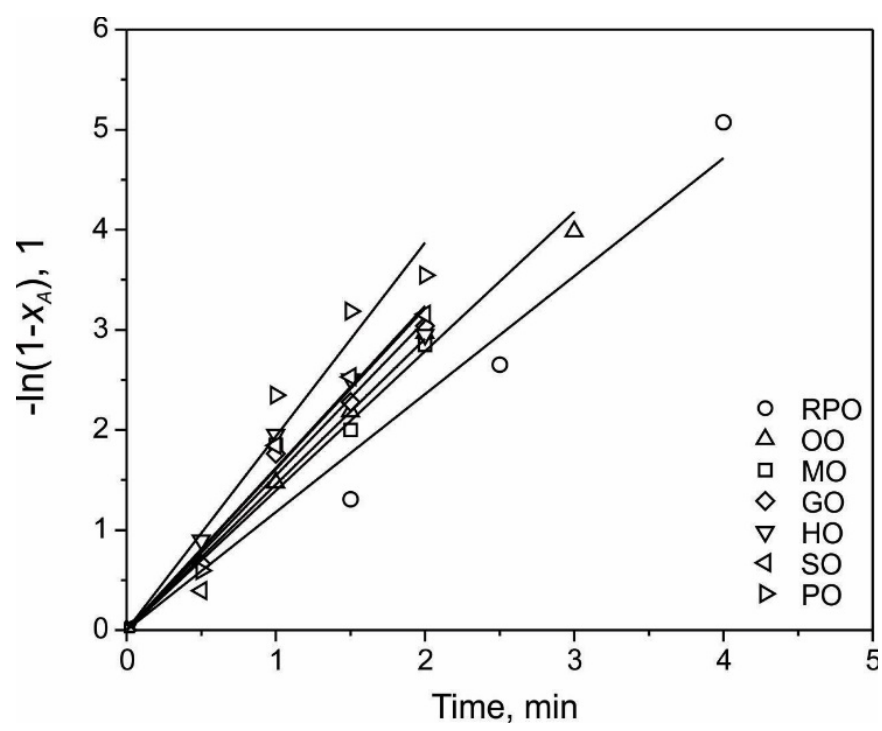

Figure 3 Plots of $-\ln \left(1-x_{A}\right)$ versus time during the methanolysis of various oils (temperature $60{ }^{\circ} \mathrm{C}$, methanol/oil molar ratio $6: 1$, and $1 \%$ of $\mathrm{KOH}$ )

Figure 4 shows the rate constant of the irreversible pseudo-first-order reaction as a function of UFA content in the oily and fatty feedstocks used in the methanolysis reactions. Generally, the rate constant can be linearly fitted with the UFA content, with the exception of OAO and SAO. This deviation could be explained by differences in the agitation intensity applied in different methanolysis reactions. The agitation intensity in the SAO methanolysis was $400 \mathrm{rpm}$ [4], which was lower compared to that applied in the methanolysis of the other feedstocks (600 rpm). The influence of agitation speed on the reaction rate was already observed, and the reaction was faster if the agitation was more vigorous $[41,42]$. Therefore, the reaction of OAO was slower compared to other oily feedstocks. Furthermore, OAO had a higher acidity $(2.89 \mathrm{mg} \mathrm{KOH} / \mathrm{g}$ ) than the recommended value for the base catalyzed methanolysis; so that the FAME synthesis from OAO was performed in two steps, i.e., by acid catalyzed esterification followed by the base-catalyzed 
methanolysis [2]. The presence of FAME in the initial reaction mixture positively influenced the reaction rate since FAME acted as a mutual solvent for the immiscible reactants and increased the interfacial area and consequently the reaction rate $[3,43]$. The higher OAO methanolysis rate was a result of the FAME content in the oil formed in the esterification of the original oil. The reaction rate constants, with exception of OAO and SAO, were linearly correlated with the TAG unsaturation degree $\left(R^{2}=0.992\right)$ :

$k_{1}=0.01834 \cdot$ UFA(\%)

where $k_{1}$ is calculated by Eq. (6).

Table 2. Rate constants for the irreversible pseudo-first-order reaction (values of rate constants are mean values of two experiments)

\begin{tabular}{llllllll}
\hline Oil & SFA, $\%$ & UFA, $\%$ & $k_{1}, \mathrm{~min}^{-1}$ & $R^{2}$ & $\begin{array}{l}\text { MRPD, } \\
\%^{*}\end{array}$ & Data & Ref \\
\hline RPO & 25.01 & 73.42 & 1.179 & 0.988 & \pm 2.7 & 9 & This work \\
OO & 16.02 & 84.87 & 1.393 & 0.997 & \pm 0.8 & 11 & \\
MO & 14.78 & 85.21 & 1.455 & 0.988 & \pm 2.2 & 11 & \\
GO & 10.86 & 89.14 & 1.544 & 0.996 & \pm 2.7 & 12 & \\
HO & 10.61 & 89.39 & 1.607 & 0.999 & \pm 2.2 & 12 & \\
SO & 10.35 & 89.65 & 1.619 & 0.988 & \pm 7.0 & 12 & \\
PO & 7.32 & 92.68 & 1.935 & 0.983 & \pm 3.8 & 12 & \\
HL & 54.97 & 45.03 & 0.949 & 0.967 & \pm 1.5 & 10 & {$[15]$} \\
L & 45.61 & 54.39 & 1.060 & 0.965 & \pm 1.6 & 11 & {$[15]$} \\
WL & 38.28 & 61.68 & 1.163 & 0.997 & \pm 3.7 & 11 & {$[15]$} \\
WCO & 10.87 & 88.79 & 1.805 & 0.970 & \pm 2.1 & 10 & {$[10]$} \\
OAO & 8.43 & 91.17 & 2.337 & 0.980 & \pm 3.9 & 12 & {$[2]$} \\
SAO & 2.61 & 97.36 & 1.196 & 0.984 & \pm 4.7 & 8 & {$[4]$} \\
\hline
\end{tabular}

* values were calculated by Eq. (7) using the values from Eq. (6)

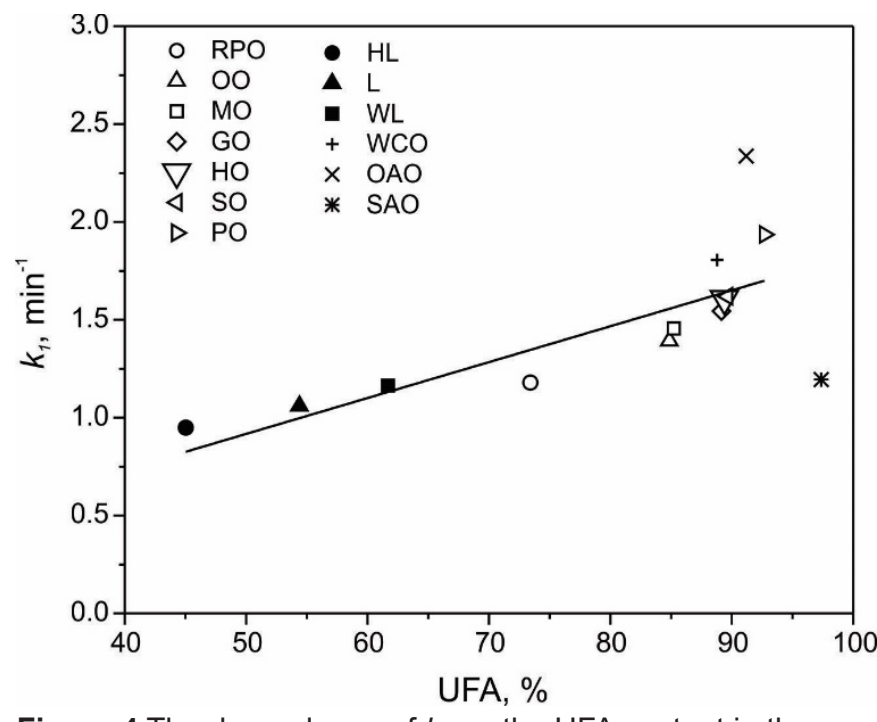

Figure 4 The dependence of $k_{1}$ on the UFA content in the feedstocks: RPO, OO, MO, GO, HO, SO, PO (this work), HL, L, WL [15], WCO [10], OAO [2], and SAO [4]

The validity of the irreversible pseudo-first-order kinetic model was checked by comparing the calculated and experimental values of TAG conversion degree with the progress of the methanolysis reaction. The TAG conversion degree is calculated by the following equation:

$x_{A}=1-\exp \left(k_{1} \cdot t\right)$

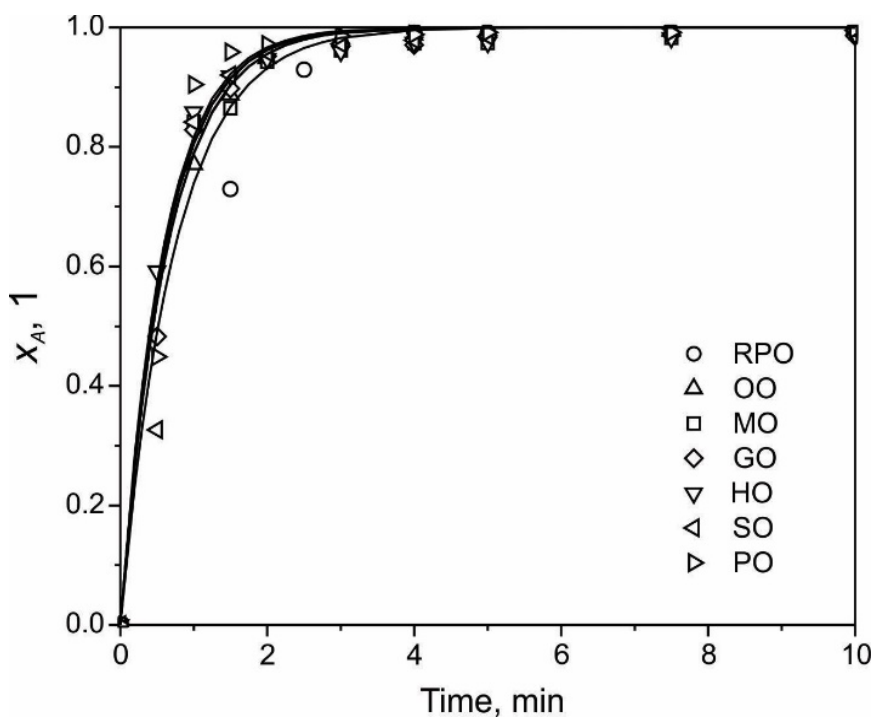

Figure 5 The comparison of the irreversible pseudo-first kinetic models (line) and the experimental data (symbols) during methanolysis of RPO, OO, MO, GO, HO, SO and PO

As can be concluded from Figure 5, there is a good agreement between the model and the experiment, which is confirmed by the low value of the mean relative deviation percentage (MRPD) $( \pm 3.1 \%$ for 79 data). The reliability of the used kinetic model was also evaluated based on the values of the coefficient of determination $\left(R^{2}\right)$ for the linear dependences shown in Figure 3 and 
the MRPD between the calculated and experimental values of TAG conversion degree for each oil type (Table 2 ). In addition, the model was verified for OAO and SAO that were not included in the analysis of dependence of the reaction rate constant on UFA content. The low $M R P D$ value between experimental and calculated value of the conversion degree of OAO and SAO $( \pm 3.9 \%$ and $\pm 4.7 \%$, respectively) validated the developed model.

\section{Conclusion}

The kinetic study of the RPO, OO, MO, GO, HO, SO, and $\mathrm{PO}$ methanolysis catalyzed by $\mathrm{KOH}$ showed that the reaction was controlled by chemical reaction while the reaction rate was influenced by the unsaturation degree of the oils. The conversion of TAGs into FAMEs followed the irreversible pseudo-first-order reaction kinetics. The reaction rate constant was linearly related to the UFA content in the oil. It was highest in the case of the PO methanolysis and lowest for RPO methanolysis. The used model is reliable for describing the methanolysis reaction rate as confirmed by a very good agreement between the model and the experiment data.

\section{Acknowledgments}

The present work has been funded by the Ministry of Education, Science and Technological development of the Republic of Serbia, Program for financing scientific research work, No.451-03-9/2021-14/200133, and it is also a part of the Project 0-14-18 of the SASA Branch in Niš, Serbia.

\section{Reference}

[1] H. V. Lee, J. C. Juan, Y. H. Taufiq-Yap, P. S. Kong, N. A. Rahman, Advancement in heterogeneous base catalyzed technology: An efficient production of biodiesel fuels, Journal Renewable Sustainable Energy, 7 (2015) 32701 - 32746.

[2] M. D. Kostić, N. M. Joković, O. S. Stamenković, V. B. Veljković, Dobijanje biodizela iz ulja semena magarećeg trna (Onopordum acanthium L.), Savremene tehnologije, 3 (2014) $35-45$.

[3] M. D. Kostić, A. V. Veličković, N. M. Joković, O. S. Stamenković, V. B. Veljković, Optimization and kinetic modeling of esterification of the oil obtained from waste plum stones as a pretreatment step in biodiesel production, Waste Management, 48 (2016) 619 - 629.

[4] M. D. Kostić, I. G. Djalović, O.S. Stamenković, P. M. Mitrović, D. S. Adamović, M. K. Kulina, V. B. Veljković, Kinetic modeling and optimization of biodiesel production from white mustard (Sinapis alba L.) seed oil by quicklimecatalyzed transesterification, Fuel, 223 (2018) 125 - 139.

[5] B. R. Moser, K. Gerhard, V. F. Steven, I. A. Terry, Production and evaluation of biodiesel from field pennycress (Thlaspi arvense L.) oil, Energy Fuels, 23 (2009) 4149 - 4155.

[6] V. Veljković, S. Lakićević, O. Stamenković, Z. Todorović, M. Lazić, Biodiesel production from tobacco (Nicotiana tabacum L.) seed oil with a high content of free fatty acids,
Fuel, 85 (2006) 2671 - 2675.

[7] S. S. Bargole, P. K. Singh, S. George, V. K. Saharan, Valorisation of low fatty acid content waste cooking oil into biodiesel through transesterification using a basic heterogeneous calcium-based catalyst, Biomass Bioenergy, 146 (2021) 105984.

[8] R. S. Nursal, A. Khalid, I. S. Abdullah, N. Jaat, N. Darlis $\mathrm{H}$. Koten, Autoignition behavior and emission of biodiesel from palm oil, waste cooking oil, tyre pyrolysis oil, algae and jatropha, Fuel, 306 (2021) 121695.

[9] S. Rezania, Z. S. Korrani, M. A. Gabris, J. Cho, K. K. Yadav, M. M. S. Cabral-Pinto, J. Alam, M. Ahamed, H. R. Nodeh, Lanthanum psosphate foam as novel heterogeneous nanocatalyst for biodiesel production from waste cooking oil, Renewable Energy, 176 (2021) 228 - 236.

[10] O. S. Stamenković, M. D. Kostić, N. M. Joković, V. B. Veljković, The kinetics of base-catalyzed methanolysis of waste cooking oil, Advanced Technologies, 4(1) (2015) $33-41$.

[11] E. Alptekin, M. Canakci, Optimization of transesterification for methyl ester production from chicken fat, Fuel, 90 (2011) 2630 - 2638.

[12] I. K. Hong, J. W. Park, S. B. Lee, Optimization of fish-oilbased biodiesel synthesis, Journal Industrial Engineering Chemistry, 19 (2013) 764 - 768.

[13] I. Idowu, M. O. Pedrola, S. Wylie, K. H. Teng, P. Kot, D. Phipps, A. Shaw, Improving biodiesel yield of animal waste fats by combination of a pre-treatment technique and microwave technology, Renewable Energy, 142 (2019) $535-542$.

[14] M. Ndiaye, A. Arhaliass, J. Legrand, G. Roelens, A. Kerihuel, Reuse of waste animal fat in biodiesel: Biorefining heavily-degraded contaminant-rich waste animal fat and formulation as diesel fuel additive, Renewable Energy, 145 (2020) 1073 - 1079.

[15] I. J. Stojković, I. B. Banković-Ilić, A. V. Veličković, J. M. Avramović, O. S. Stamenković, D. S. Povrenović, V. B. Veljković, Waste lard methanolysis catalyzed by potassium hydroxide at moderate temperatures, Chemical Engineering Technology, 39 (2016) 741 - 750.

[16] S. M. Pavlović, D. M. Marinković, M. Kostić, I. M. JankovićČastvan, Lj. V. Mojović, M. V. Stanković, V. B. Veljković, A $\mathrm{CaO} /$ zeolite-based catalyst obtained from waste chicken eggshell and coal fly ash for biodiesel production, Fuel, 267 (2020) 117171.

[17] Y. H. Tan, M. O. Abdullah, C. Nolasco-Hipolito, Y. H. Taufiq-Yap, Waste ostrich- and chicken-eggshells as heterogeneous base catalyst for biodiesel production from used cooking oil: Catalyst characterization and biodiesel yield performance, Applied Energy, 160 (2015) 58 - 70.

[18] P-L. Boey, G. P. Maniam, S. A. Hamid, Biodiesel production via transesterification of palm olein using waste mud crab (Scylla serrata) shell as a heterogeneous catalyst, Bioresource Technology, 100 (2009) 6362 - 6368

[19] A. Birla, B. Singh, S. N. Upadhyay, Y. C. Sharma, Kinetics studies of synthesis of biodiesel from waste frying oil using a heterogeneous catalyst derived from snail shell, Bioresource Technology, 106 (2012) 95 - 100.

[20] E. Betiku, O. R. Omilakin, S. O. Ajala, A. A. Okeleye, A. E. Taiwo, B. O. Solomon, Mathematical modeling and process parameters optimization studies by artificial neural network and response surface methodology: $A$ case of non-edible neem (Azadirachta indica) seed oil biodiesel synthesis, Energy, 72 (2014) 266 - 273. 
[21] E. Betiku, A. M. Akintunde, T. V. Ojumu, Banana peels as a biobase catalyst for fatty acid methyl esters production using Napoleon's plume (Bauhinia monandra) seed oil: A process parameters optimization study, Energy, 103 (2016) 797 - 806.

[22] E. Betiku, A. O. Etim, O. Pereao, T. V. Ojumu, Two-step conversion of neem (Azadirachta indica) seed oil into fatty methyl esters using a heterogeneous biomass-based catalyst: an example of cocoa pod husk, Energy Fuels, 31 (2017) 6182 - 6193.

[23] M. D. Kostić, A. Bazargan, O. S. Stamenković, V. B. Veljković, G. McKay, Optimization and kinetics of sunflower oil methanolysis catalyzed by calcium oxidebased catalyst derived from palm kernel shell biochar, Fuel, 163 (2016) 304 - 313.

[24] D. R. Đokić-Stojanović, Z. B. Todorović, D. Z. Troter, O. S. Stamenković, L. M. Veselinović, M. V. Zdujić, D. D. Manojlović, V. B. Veljković, Influence of varios cosolvents in the calcium oxide-catalyzed ethanolysis of sunflower oil, Journal Serbian Chemical Society, 84 (2019) 253 - 265.

[25] D. Z. Troter, Z. B. Todorović, D. R. Đokić-Stojanović, L. M. Veselinović, M. V. Zdujić, V. B. Veljković, Choline chloride-based deep eutectic solvents in $\mathrm{CaO}$-catalyzed ethanolysis of expired sunflower oil, Journal Molecular Liquids, 266 (2018) 557 - 567.

[26] A. Bokhari, S. Yusup, R. N. M. Kamil, J. Ahmad, Blending study of palm oil methyl esters with rubber seed oil methyl esters to improve biodiesel blending properties, Chemical Engineering Transactions, 37 (2014) 571 - 576.

[27] K. G. Georgogianni, M. G. Kontominas, P. J. Pomonis, D. Avlonitis, V. Gergis, Alkaline conventional and in situ transesterification of cottonseed oil for the production of biodiesel, Energy Fuels, 22 (2008) 2110 - 2115.

[28] K. G. Georgogianni, M. G. Kontominas, P. J. Pomonis, D. Avlonitis, V. Gergis, Conventional and in situ transesterification of sunflower seed oil for the production of biodiesel, Fuel Processing Technology, 89 (2008) 503 -509 .

[29] A. Z. Jamil, A. Muslim, Performance of $\mathrm{KOH}$ as a catalyst for transesterification of Jatropha curcas oil. International Journal Engineering Research Applications, 2 (2012) 635 $-639$.

[30] R. A. Rabu, I. Janajreh, D. Honnery, Transesterification of waste cooking oil: Process optimization and conversion rate evaluation, Energy Conversion Management, 65 (2013) 764 - 769.

[31] G. Vicente, M. Martinez, J. Aracil, A. Esteban, Kinetics of sunflower oil methanolysis, Industrial Engineering Chemistry Research, 44 (2005) 5447 - 5454.

[32] G. Vicente, M. Martinez, J. Aracil, Kinetics of Brassica carinata oil methanolysis, Energy Fuels, 20 (2006) 1722 $-1726$.

[33] AOCS. Official and Tentative Methods; American Oil Chemists' Society: Chicago, 1980.

[34] I. Stanisavljević, S. Lakićević, D. Veličković, M. Lazić, V. Veljković, The extraction of oil from tobacco (Nicotiana tabacum L.) seeds, Chemical Industry Chemical Engineering Quarterly, 13 (2007) 41 - 50.

[35] M. R. Miladinović, O. S. Stamenković, V. B. Veljković, U. D. Skala, Continuous sunflower oil methanolysis over quicklime in a packed-bed tubular reactor, Fuel, 154 (2015) 301 - 307.

[36] M. Su, R. Yang, M. Li, Biodiesel production from hempseed oil using alkaline earth metal oxides supporting copper oxide as bi-functional catalysts for transesterification and selective hydrogenation, Fuel, 103 (2013) 398 - 407.

[37] N. Canha, P. Felizardo, J. C. Menezes, M. J. N. Correia, Multivariate near infrared spectroscopy models for predicting the oxidative stability of biodiesel: Effect of antioxidants addition, Fuel, 97 (2012) 352 - 357.

[38] S. Pinzi, L. M. Gandía, G. Arzamendi, J. J. Ruiz, M. P. Dorado, Influence of vegetable oils fatty acid composition on reaction temperature and glycerides conversion to biodiesel during transesterification, Bioresource Technology, 102 (2011) 1044 - 1050.

[39] S. Pinzi, J. M. Mata-Granados, F. J. Lopez-Gimenez, M. D. Luque de Castro, M. P. Dorado, Influence of vegetable oils fatty-acid composition on biodiesel optimization, Bioresource Technology, 102 (2011) 1059 -1065.

[40] J. Sáez-Bastante, S. Pinzi, G. Arzamendi, M. D. Luque de Castro, F. Priego-Capote, M. P. Dorado, Influence of vegetable oil fatty acid composition on ultrasound-assisted synthesis of biodiesel, Fuel, 125 (2014) 183 - 191.

[41] O. S. Stamenković, M. L. Lazić, Z. B. Todorović, V. B. Veljković, D. U. Skala, The effect of agitation intensity on alkali-catalyzed methanolysis of sunflower oil, Bioresource Technology, 98 (2007) 2688 - 2699.

[42] H. von Blottnitz, S. A. Sadat-Rezai, J Vardy, Conversion of plant oils to methyl-ester fuels: consideration for reactor design in commercial and small-scale production. In: 16th International Congress of Chemical and Process Engineering, CHISA 2004, 22-26 August, 2004. Prague, Czech Republic. CD ROM of Full Texts 1361.pdf.

[43] J. Y. Park, D. K. Kim, Z. M. Wang, J. S. Lee, Fast biodiesel production with onephase reaction, Applied Biochemistry Biotechnology, 154 (2009) 246 - 252. 


\section{Izvod}

\section{UTICAJ SASTAVA MASNIH KISELINA NA BRZINU REAKCIJE METANOLIZE BILJNIH ULJA}

Milan D. Kostić ${ }^{1}$, Olivera S. Stamenković ${ }^{1}$, Vlada B. Veljković ${ }^{1,2}$

(ORIGINALNI NAUČNI RAD)

UDK 662.756.3:66.09

${ }^{1}$ Tehnološki fakultet u Leskovcu, Univerzitet u Nišu, Leskovac, Srbija

DOI 10.5937/savteh2102024K

${ }^{2}$ Srpska akademija nauke i umetnosti, Beograd, Srbija

Bazno katalizovana metanoliza ulja iz semena smrdljive čestike, semena dinje, konoplje, jezgra šljive, kao i maslinovog, suncokretovog i ulja iz semenki grožđa je vršena u prisustvu $\mathrm{KOH}\left(1 \%\right.$, računato na masu ulja), temperaturi od $60{ }^{\circ} \mathrm{C}$ i molskom odnosu metanol:ulje 6:1. Cilj ovog rada je modelovanje kinetike reakcije transesterifikacije i ispitivanje uticaja masno-kiselinskog sastava ulja na konstantu brzine reakcije konverzije triacilglicerola u metil estre masnih kiselina. Za modelovanje rekcije metanolize biljnih ulja korišćen je model nepovratne reakcije pseudoprvog reda, a konstanta brzine reakcije je korelisana sa udelom nezasićenih masnih kiselina u ulju. Vrednosti konstante brzine reakcije povećavaju se linearno sa povećanjem udela nezasićenih masnih kiselina u ulju. Visoke vrednosti koeficijenta determinacije i niske vrednosti srednjeg relativnog procentnog odstupanja primenjenog kinetičkog modela pokazuju da je model primnljiv i pouzdan za modelovanje reakcije metanolize biljnih ulja.
Ključne reči: biodizel; kinetika; metanoliza; nezasićene masne kiseline: ulje 